\title{
COCONUT RESEARCH AND DEVELOPMENT IN THE PHILIPPINES
}

\author{
Dely P. Gapasin*
}

\begin{abstract}
SUMMARY
Research and development programs in agriculture and natural resources are planned, monitored and evaluated by the Philippine government through the Philippine Council for Agriculture and Resources Research and Development (PCARRD) in cooperation with the National Agriculture and Resources Research System (NARRS) and the private sector. Within the NARRS, the Philippine Coconut Authority (PCA) is the national center for coconut research.

The $\mathrm{R}$ and $\mathrm{D}$ programs on coconut support the national goals of attaining sustainable economic growth, equitable distribution of products of development and total human development, Priority areas have been identified to meet the needs of the industry, while a number of programs have been launched to solve the pressing problems of the industry. Support to coconut R and D programs comes from the Philippine government, the private sector and through foreign linkages.
\end{abstract}

Major breakthroughs in coconut $\mathrm{R}$ and $\mathrm{D}$ programs, as well as the strategies being pursued by the government and the private sector are described in this paper.

\section{INTRODUCTION}

The Philippines is the world's largest coconut producer. It contributes about $71 \%$ of the total world export of coconut oil and copra cake. In 1983, the earnings from the coconut, industry was about US \$ 682 million. About 14 million Filipinos directly or indirectly rely on the coconut industry for livelihood. As one of the pillars of the Philippine economy, the coconut industry enjoys government support for its continuing development.

In spite of its national economic importance, the Philippine coconut industry is still laden with problems. In the world market, price of copra fluctuates; while in the farm, productivity is low. In 1982 , the national average yield for copra is only $1.36 \mathrm{t} / \mathrm{ha}$.

\section{The National Agriculture and Resources Research System (NARRS) and PCARRD}

The national and regional research centers, as well as cooperating stations, compose the NARRS which generate technologies in crop production and post production. Basic and applied researches in agricultural crops are conducted in national research centers to give or offer solutions to constraints of national or general concern.

The national research center develops body of knowledge from where the regional or local research stations draw technologies for verification and adaptation. This body of knowledge is the constant source of technology for verification and/or pilot testing. Verification and on-farm trials in specific areas where regional research centers and cooperating stations are located, integrate the agro-climatic and socio-economic considerations, as well as the priority needs of the end-users, of the technologies generated.

*Director, Crops Research Department, Philippine Council for Agriculture and Resources Research and Development (PCARRD), Los Banos, Laguna. 
In 1972, the Philippine Council for Agriculture and Resources Research and Development (PCARRD) has been established and mandated to provide a systematic approach to the planning, coordinating and directing of the country's research and development $(R \& D)$ program for agriculture and natural resources. PCARRD coordinates and integrates the research activities of the government bureaus and agencies as well as ensures the involvement of colleges and universities within the National Agriculture and Resources Research System (NARRS). To carry out its mandate, PCARRD has a secretariat with seven technical departments. One of these departments is the Crops Research Department which monitors $\mathrm{R}$ and $\mathrm{D}$ activities, packages generated technology and disseminates technology on 12 commodities, coconut being one of these commodities.

Within the NARRS, the Philippine Coconut Authority is the national center for coconut research. Its four research centers are distributed over the country, with definite major aspects of research responsibility (Fig. 1) The research center at Guinobatan, Albay deals on tissue c4ture and cadang-cadang research, at San Ramon, Zamboanga City for genetics, breeding and timber researches; at Bago-Oshiro, Davao, City for agro-soils and crop protection as well as for the PCA Coconut Extension and Training Center. The National Center at Diliman, Quezon City deals with tissue analysis and biometrics studies aside from the general management and administration. The regional centers for coconut research are located at the Visayas State College of Agriculture (ViSCA) at Baybay, Leyte and at the University of the Philippines at Los Banos (UPLB), Los Banos, Laguna. The cooperating stations are Palawan National Agricultural College (PNAC) Aborlan, Palawan; Bicol University College of Agriculture (BUCA), Guinobatan, Albay; University of Eastem Philippines (UEP) Catarman, Northern Samar; and the Twin Rivers Research Center (TRRC), Tagum, Davao del Norte.

Other government institutions which conduct coconut researches on some limited disciplines such as processing and utilization are the Forest Products Research and Development Institute (FPRDI), the National Institute of Science and Technology (NIST), the Food and Nutrition Research Institute (FNRI) and the University of the Philippines Systems (UPS).

Supportive to research activities of the institutions are the Philippine Coconut Producers Federation, Inc. (COCOFED) which acts as the linkage between the government and the farmers, and the United Coconut Association of the Philippines (UCAP) which integrates data based on markets and trade. Aside from these, private cooperators such as the Agricultural Investors, Inc. (AII), which provide funds and seeds of hybrids, and TRRC, which provides seeds of hybrids, act as cooperators; for the Regional Testing of Promising Coconut Hybrids and Cultivars.

\section{R and D Thrusts and Priorities}

$\mathrm{R}$ and $\mathrm{D}$ programs in agriculture and natural resources support the national goals of attaining sustainable econornic growth, equitable distribution of the products of development and total human development. The prograrn thrusts consist of food nutrition, export generation, energy, import

substitution, income generation and distribution, conservation and resource management, socio-economics, and countryside development.

The $\mathrm{R}$ and $\mathrm{D}$ program on coconut As a translation of the national thrusts. Its priority research areas have been identified as fonows:

Priority I

o Processing and utilization coconut products and by-products for food and industrial purposes 


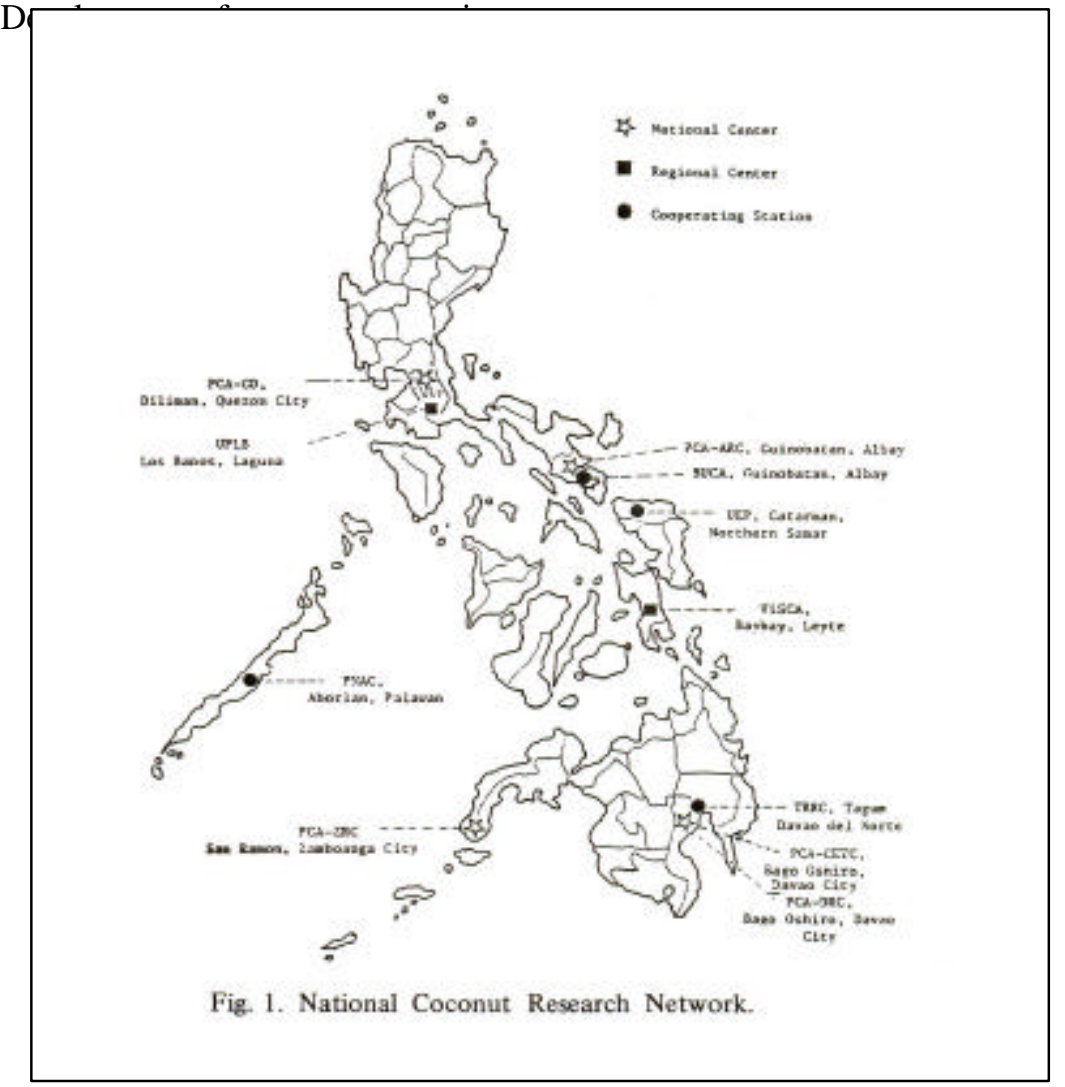

o Marketing systems for more equitable sharing of benefits among farmers and processors.

o Socio-economic structure and tenure relations in coconut farming system

o Improvernent of labor and land productivity

o Determination of information needs of the farmers, socio-cultural economic factors hindering technology adoption, extension and credit services

o Vertical and horizontal integration of production, marketing and processing at various levels.

International trade of coconut products and by-products

o Development of integrated coconut-based farming systems

Priority II

o Physiology and morphology studies of coconut

o Soils and plant nutrition of non-bearing and bearing coconut and of coconut intercrops

o Utilization of organic sources of fertilizer 
o Population dynamics of major pests and natural enemies

o Development of integrated pest management strategies for major insect pests and diseases

\section{Priority III}

o Development of screening techniques for identification and evaluation of cultivars

o Breeding for specific objectives

These priority areas have been drawn up to meet the needs of the industry, and in consonance to the national development goals. Among major goals toward solutions to the problems of the industry are product, diversification and processing, agro-climatic and socio-economic studies and increased production.

\section{National Programs on Coconut}

The Philippine government launched a number of research and development programs to solve the pressing problems of the industry. One of these programs is the National Coconut Productivity Prograrn (NCPP) which is implemented nationwide by the Philippine Coconut Authority (PCA). This program. aims to arrest declining coconut production, to increase coconut production, to stabilize supply availabilities of coconut products and by-products, and to maximize profitability of coconut farming.

Another program launched by PCA in 1982 is the National Coconut Intercropping Project (NCIP), The prograrn seeks to promote the benefits from intercropping, particularly in providing farmer with a regular added source of income at relatively small incremental cost. The program implementation follows the selfhelp concept wherein the farmer undertakes aH operations, while PCA provides the necessary fann, marketing and credit assistance. The farmer-participants in the program are owner-cultivators of not less than one hectare. They are entitled to a loan package which covers the expenses for planting materials and other agricultural inputs and contingency.

The Ministry of Agriculture and Food (MAF) formulated two projects on coconut intercropping, namely the Multi-Storey Cropping and the Multiple Cropping Projects. The Multi-Storey Cropping is a kind of multiple cropping system for established coconut plantations wherein several perennials are combined with few annuals. The main objectives of the project are to increase food production through maximized land utilization, to improve nutrition and augment farmer's income. This specifically aims to develop one hectare demonstration farms at strategic places in selected coconut and intercrops, to determine the effects of intercropping on income and nutrition, and to provide support services such as input, marketing and technical assistance. The Multiple Cropping Project aims to encourage coconut farmers to intercrop using quality planting materials to increase agricultural production through maximized land utilization. It specifically aims to provide farmers with high quality seeds and planting materials, to evaluate the effects of multiple cropping under coconut on the socio-economic conditions of the farmers, and to generate appropriate intercropping technology for coconut farmers.

The Philippine government, through the PCA, PCARRD, UPLB and VisCA, together with the private sector, e.g. All and TRRC launched in 1983 the project on the "Regional Testing of Promising Coconut Hybrids and Cultivars". It aims to select promising hybrids and cultivars for replanting or planting and, to test these promising hybrids and cultivars in different agroclimatic zones in the Philippines. It has four phases, namely; (1) initial evaluation of hybrids, entry and site selection, (2) seed production, (3) nursery establishment and seedling management. (4) field planting and evaluation of performance of hybrids. The project is now on the third phase, and its success will complement the 
National Coconut Productivity Program, popularly known as the National Coconut Replanting Program of the government.

\section{Support to Coconut Programs}

The Philippine government supports coconut R and D programs through the PCA and PCARRD. Besides, the Philippine Coconut Research and Development Foundation, Inc. (PCRDF) funds R and D efforts as well as publications. Foreign funding comes from the International Plant Breeding and Genetic Resources (IPBGR) for varietal improvement studies; from the United Nations Development Program (UNDP) for cadang-cadang studies, control of rhinoceros beetle and agro-soil studies, from the Food and Agriculture Organization (FAO) for timber processing and utilization; and from the World Bank for the National Coconut Intercroping Program (NCIP), At present proposals on coconut-based farming systems and food processing are being packaged for possible submission to the French government and the Federal Government of Germany, respectively.

Figure 2 shows that in 1984, of the total support to crops $\mathrm{R}$ and $\mathrm{D}$, the highest was on coconut (17.7\%), followed by root crops (13.3\%), tobacco (9.5\%), fiber crops $(9.4 \%)$ and corn and sorghum (8.9\%). In 1985, the highest support is on root crops $(19.73 \%)$, followed by corn and sorghum $(13.88 \%)$, tobacco $(9.46 \%)$, legurnes $(9.19 \%)$ and coconut $(9.16 \%)$.

\section{Research Status and Plans}

Researches on coconut have been conducted on different disciplines such as crop improvement, crop production, crop protection, faryning systems, post-harvest handling as well as processing and utilization, socio-economics and marketing. Major breakthroughs since 1980 and the present research in each discipline are presented here.

\section{Crop Improvement}

Gennplasm collection. Activities on crop improvement have been focused on germplasm collection, preservation and evaluation in quest of better cultivars and screening techniques. At present, 71 populations are planted at PCA-Zamboanga Research Center, so far the largest and most varied assemblage of coconut in Asia with emphasis on local genetic resources (Table 1). The collection includes some introduced germplasm (Table 2). Started in 1981, this regional collection is planted in about 100 hectares and supported by PCA, PCARRD and IBPGR (International Board for Plant Genetic Resources).

Among the promising coconut varieties and cultivars are:

Tall - Typica, Spicata, Pag-asa, Macapuno, Bago Oshiro, Baybay, Laguna, Tagnanan, San Ramon

Dwarf - Javanica, Nana, Bilaka, Coconino, kinabalan, Makilala, Lanao Green Dwarf, Rabara, Pilipog, Tacunan

Hybrid - MAWA-Y (Yellow Malayan Dwarf x West African Tall)

Some coconut hybrids from foreign and local varieties produced by several Philippine institutions showed potential as superior planting materials. The strategy using selection and testing of these hybrids in different agro-chmatic zones in the country is being implemented in the project entitled "Regional Testing of Promising Coconut Hybrids and Cultivars". This project is the first and the biggest collaboration between the private sector and the government in coconut $\mathrm{R}$ and $\mathrm{D}$. It is being supported by AII and PCARRD, and implemented by PCA-ZRC, TRRC, UPLB, VISCA and AII. 


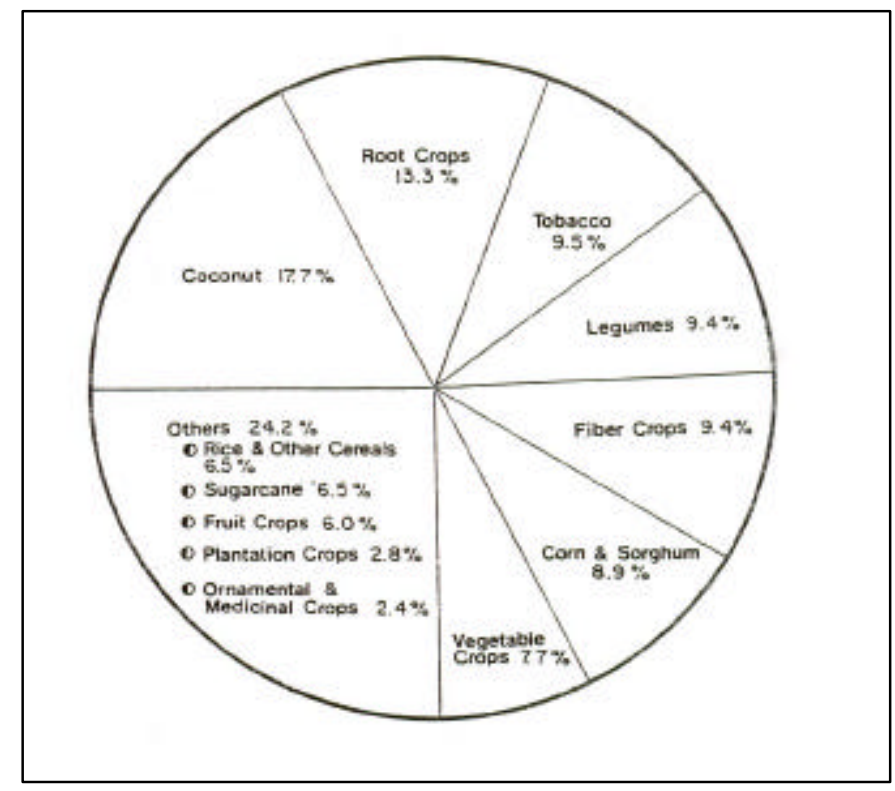

Fig. 2. CY 1984 National Crop Research and Development Program Budgetary Support

Table 1. Distribution of coconut collections at PCA research centers

\begin{tabular}{|c|c|c|c|}
\hline TYPE & DAVAO & ALBAY & ZAMBOANGA \\
\hline Tall & 4 & 11 & 44 \\
Dwarf & 7 & 12 & 20 \\
Hybrid & 0 & 8 & 5 \\
Self & 0 & 0 & 2 \\
\hline TOTAL & 11 & 31 & 71 \\
\hline
\end{tabular}

Macapuno embryo culture. The regular macapuno bearing palm. produces 3 to $22 \%$ macapuno, nuts. However, scientists at UP at Los Banos developed the technology wherein macapuno embryos are grown in test tubes or bottles containing artificial media and plantlets are transferred to polybags in the greenhouse before planting in the field. The macapuno palms yield from $92 \%$ to $100 \%$ macapuno nuts under controlled pollination.

\section{Crop Production}

Fertilization of coconut. Coconut treees are not usually fertilized. However, PCA has developed a technology wherein nitrogen and chlorine are applied as $2.2 \mathrm{~kg}$ ammonium sulfate, $1.0 \mathrm{~kg}$ 
superphosphate and $1.5 \mathrm{~kg}$ potassium chloride per tree per year to trees about 5 years old or more. Fertilization increased nut and copra yield by $230 \%$. In 1981, the net income was almost tripled.

Research results showed that the by-product of Eucheuma spinosum, a seaweed, is a suitable substitute for $\mathrm{KCl}$ fertilizer for coconut seedlings.

Table 2. Population of coconut collected from foreign countries

\begin{tabular}{|c|c|c|c|}
\hline POPULATION & ORIGIN & SOURCE & $\begin{array}{c}\text { NUMBER OF } \\
\text { PALMS }\end{array}$ \\
\hline \multicolumn{4}{|l|}{ Tall } \\
\hline West African & Ivory Coast & IRHO & 143 \\
\hline Tahiti & Polynesia & IRHO & 123 \\
\hline Rennel & Solomon Is. & Solomon Islands & 565 \\
\hline Vanuatu & New Hebrides & IRHO & 81 \\
\hline Markham & Papua New Guinea & PNG & 156 \\
\hline Karkar & Papua New Guinea & PNG & 148 \\
\hline Gacelle & Papua New Guinea & PNG & 151 \\
\hline \multicolumn{4}{|l|}{ Dwarf } \\
\hline Yellow Malayan* & Ivory Coast & IRHO & 1005 \\
\hline Red Cameron* & Ivory Coast & IRHO & 168 \\
\hline $\begin{array}{l}\text { Equatorial Guinea } \\
\text { Green* }\end{array}$ & Ivory Coast & IRHO & 133 \\
\hline Aromatic & Thailand & Los Banos (Phil.) & 135 \\
\hline
\end{tabular}

*Inbreds segregated from the hybrid introduction in 1976.

Tissue analysis for fertilizer recommendation. Since 1974, PCA researchers worked on assessing the nutritional status and fertilizer needs of selected coconut areas in the country on the basis of foliar diagnosis; complemented by soil analysis. Leaf tissue analysis provides indirect evidence of the nutritional status or requirement of bearing palms grown in different agro-climatic regions. Balanced nutrition, including $\mathrm{Cl}$ and $\mathrm{S}$ levels of coastal coconuts, contributes to higher yields compared to inland coconuts as supported by leaf and soil analysis. A nutrient deficiency map of the Philippines has been developed by PCA for the purposes of planning, developing and implementing a national program on coconut fertilization in the future.

\section{Farming Systems}

Multiple cropping in coconut. Mixed cropping benefits both the coconut tree and the farmers, since weeds are controlled, soil is conserved, nut production is increased, income is increased and stabilized, family is given additional employment, land is efficiently utilized. In 1981, a return of P 
1.29 to P3.34 per peso invested was realized by intercroping a combination of papaya, pineapple, banana, and gabi with coconut. Nut production increased by $25 \%$ and copra production per tree increased by $30 \%$ when black pepper, cacao and pineapple, intercrops were fertilized. Thus, with a net income of about P4,500 from coconut and 9,113 from intercrops, a farmer with an intercropped 2-ha coconut farm expects and annual net income of P13,613.

In 1985, the number of bunch, fruit set and full-grown nuts increased significantly with greater cropping intensity, as the weight of shell, copra per nut and volume of whole nuts tended. to be higher in more intensely cropped farms. Significantly more nuts (64 to $90 \%$ increase) and higher copra per tree (70 to $105 \%$ increase) were produced in intercropped farms than. in monocropped coconut plantations.

Besides improving the productivity of the coconut land, mixed cropping increases employment opportunities for agricultural workers. As an example, a pure stand of coconut requires 150 man days/yr which can be raised to at least 500 man-days/yr for mixed crop/commodity management, harvesting and processing. In 1983, a cropping pattern of coconut -pineapple-papaya, was reported to require 168 man-days/yr while coconut-coffee-banana-pineapple-papaya requires 202 man-days/yr. These patterns done in Silang, Cavite, Philippines gave a net income of r 3,650 in the former and P 7,234 in the latter.

Integrated cattle-coconut farming In 1982, about $22 \%$ of the $3.1 \mathrm{M}$ ha planted to coconut was stocked with cattle, carabaos and goat, which were either tethered or allowed to graze under coconut. In a 4-ha farm, the average net return per hectare over a 10-year period of operation under different management schemes is as follows: (a) coconut farm (traditional management) P620; (b) cattle-coconut farm (traditional management); and (c) cattle-coconut farm (improved management), P3.100. Aside from the economic benefits, cattle-coconut farming maintains a productive plantation wherein weeds and bushes are controlled as improved grasses and legumes which serve as cover-crops increase soil fertility; maximizes utilization of available farm resources, such as family labor; increases present supply of meat and milk products; and compels the coconut farmer to spend relatively more time at the plantation thus, as he manages his animals, he discourages filferage of the coconuts.

Livestock raising under coconut as experienced in pilot projects conducted in the provinces of Laguna and Quezon indicated problems that hamper backyard forage production. Among these problems are insufficient feed for the livestock throughout the year, depressing effects of grazing on the yield of coconut, and inagequate financing.

\section{Crop Protection}

Major pests cause not only low yield but death as well of the coconut in the Philippines. The pests are insects. plant pathogens, weeds and vertebrates such as rodents.

Chemical control In 1980, when the Philippine government launched a massive coconut replanting program, fears existed that this move might create new second generation problems concerning the major pests, i. e., the rhinoceros beetle. Upon cutting down of the coconut tree, favorable breeding sites become available, and this may result to an increase in beetle population. Chemical control of rhinoceros beetle by leaf axil placement of granular insecticides, eg. carbosulfan and pirimiphos ethyl, carbosulfan and diazinon had been recommended on young palms at monthly intervals.

For the past 50 years, cadang-cadang, which has been reported to be caused by a viroid, has been studied extensively. More recently, research has been with emphasis on the development of integrated 
pest management strategies for rhinoceros beetle, Asiatic palm weevil, slug caterpillar, spike moth, cadang-cadang, bud rot, leaf spot, rats and the most recently reported disease in the isolated island of Mincloro called 'Socorro Wilt'.

Biological control. Researches on biological control of important pests have been done mostly by PCA-ARC on rhinoceros beetle and ViSCA for coconut slug caterpillar, gelatin slug, and coconut leafminer. PCA-ARC mass reared Oryctes rhinoceros and purified the Oryctes baculovirus to parasitize the larvae of rhinoceros beetle in the coconut plantation. On the other hand, ViSCA has been working on the potential biological control agents such as Apanteles sp. against Thosea cinereomarginata, Aeronia sp. against gelatin slug, and Sympieses sp. against leaf miner.

Rat control Rat control can be effectively done either by trunk banding with metal sheets, 30 to $40 \mathrm{~cm}$ wide, or by baiting with chronic poison mixed with roasted grated coconut or rice. Over a 10 -year period, a farmer gets a cost benefit ratio of 1/P 13.54 with trunk banding of 100 coconut tress in one hectare plantation. Meanwhile, with ground baiting of $10 \mathrm{tress} / \mathrm{ha} / \mathrm{yr}$, he gets a cost-benefit ratio of 1/P I.73 and with croun baiting, he gets 1/P 12.39.

\section{Postharvest Handling, Processing and Utilization}

Downward trends in the world market for coconut oil and copra necessitate exploration and development of other products and/or by-products from coconut. Further studies on the improvement of quality, development of low cost technology for efficient processing of other products/by-products, and diversification of product uses are the focus of the present Coconut $\mathrm{R}$ and D Program. These include utilization of waste materials for energy, processing of other products/by-products for food and feed and development of industrial products in line with the national thrusts on energy and food production. Emphasis, however, is on village-level processing and utilization.

As Food Mature nuts have been used for the production of copra, coco chips, desiccated coconut (dried grated meat), and coconut milk. The young coconut or immature nut (buko) has been used for beverage, snack items, like buko pie, espasol, bukayo. Dried buko strips have also, been produced from the young nuts. Immigration of Filipinos abroad has created considerable demand for coconut milk, hence the development of a canned coconut milk formulation and powdered coconut milk.

The Institute of Food Science and Technology (IFST) at UP at Los Banos studied the utilization of coconut milk into dairy type products. It developed a technology producing soft cheese from a combination of coconut milk and non-fat dry milk, with the resulting product being comparable to the soft cheese made from $100 \%$ cow's milk in terms of flavor, aroma, texture and general acceptability. Coconut skim milk (CSM) has also been used in the preparation of the fermented beverage concentrate which is known as reidy-to-drink CSM fermented beverage. It gives a return per peso invested of P2.10 based on 1985 prices. IFST has also formulated from dried SCM the evaporated milk and condensed milk type products which have been successfully incorporated in some food preparations such as ice cream, confectionaries and selected bakery products.

As industrial and housing materials. The Forest Products Research and Development Institute (FPRDI) developed cellulose nitrate from coconut (CNC) from coconut trunk high-alpha pulp. The lacquer sanding sealer prepared from $\mathrm{CNC}$ is within the standard specifications for lacquer. It also developed hollow blocks and other strong materials made of coconut coir-dust which can be commercialized to provide cheap construction materials to people in the countryside. Aside from these, particle boards from debarked coconut trunk and petide passed the minimum specifications for mechanical properties set by the Philippine Standards Association (PHILSA) for mediurn density boards. Studies conducted by FPRDI showed that cocowood can compare to narra, yakal and dao in 
durability, sturdiness, and versatility at considerably less cost. In general, the production cost of cocowood per board foot ranges from P0.75 to P1.45. Based on 1985 selling price, cocowood costs commercially at P2.20 to $\mathrm{P} 2.40 / \mathrm{bd}$. ft while the traditional lumber cost P 4.00 or higher/bd. ft. Cocowood, as a material for conventional lumber, as construction material, brings down the cost of housing unit. Cocowood can also be made into columns, beams, parquet flooring, walling, panels, rafters, joists, studs, shingles and novelty items can be made out of cocowood's shave -off waste materials. These can boost the handicraft industry through production of coffee tables, dining tables, chopping board, knife block, ash tray, utility boxes and cigarette cases. FPRDl also developed a drying technique for coconut -sawn lumber, as well as the preservative treatment of coconut pole and lumber.

\section{Concluding Rernarks}

The major socio-economic impact of the coconut industry in the Philippines is based on the foreign exchange earnings and the large proportion of the people dependent on it. Solutions to the problems related to coconut production and post-production activities are the main targets of the national. $\mathrm{R}$ and $\mathrm{D}$ programs of the government. Aside from the academe, the private sector represented by the producers, exporters and financiers, helps the government in supporting the R and $\mathrm{D}$ endeavors.

To attain self-sufficiency and solve the constraints to the development of the industry, there are strategies being pursued by the govemment and the private sector. The programs on coconut $\mathrm{R}$ and $\mathrm{D}$ are being documented and prioritized, underscoring those with immediate impact to the coconut farmers. The research results are widely circulated through the extension network of both the govemment and private sector. While the private sector assesses the products' market possibilities, the govemment extension men assess the receptivity of the end-users. Besides, the government creates an environment that is conducive for $\mathrm{R}$ and $\mathrm{D}$ linkages with funding institutions. Complementary to this is the market development efforts: the search for new markets, the increase in market share and the conduct of the new product $\mathrm{R}$ and $\mathrm{D}$. Thus the Philippines is actively supporting its coconut $\mathrm{R}$ and $\mathrm{D}$ programs with dynamism and sincere commitment. 


\section{REFERENCES}

FLORIA, ROLANDO N. 1983. National coconut intercropping project: PCA Pilot Project. In Proceedings: Symposium on Coconut -based Farming Systems, June 1-3, 1983. Visayas State College of Agriculture, Baybay, Leyte, Philippines. 9-11

GAPASIN, DELY P. 1983. The national coconut-based farming system research and development program. In Proceedings: Symposium on Coconut based Farming Systems, June 1-3, 1983. Visayas State College of Agriculture, Baybay. Leyte, Phifippines. pp. 7 -8.

MAGAT, SEVERINO, S., J.A. HABANA, A.G. ESCOTON, A.D. LABARCON, and L.B. ROILAN, 1981,. Mineral nut ritio (leaf) survey of coconut in the Philippines. 1. Nutritional deficiency and fertilization. PCADRC, Bago Oshiro, Davao City, Phil. Mimeog.

PCARRD. 1980 Rat control in coconut. Technology 2(8): 1-12

PCARRD. 1981. Multiple Cropping in Coconut. Technology 3 (6): 1-10

PCARRD. 1982. Fertilization of coconut. Technology! 4(3):1-12.

Research Highlights from the PCARRD Network. 1983 and 1984 Philippine Council for Agriculture and Resources Research and Development. Los -Banos, Laguna, Philippines. 266 and 216 pp. respectively.

TARIGANS, DOAH DEKOK. 1985. Growth of coconut (Cocos nucifera $\mathrm{L}$ ) and soil properties under six cropping patterns. Ph. D. dissertation, UP at Los Banos, College, Laguna, Philippines, $245 \mathrm{pp}$.

The PCARRD Corplan 1984-1988: Priming Rural Development through Research. 1983 Philippine Council for Agriculture and Resources Research and Development, Los Banos, Laguna, Philippines. 99 pp.

The Coconut Committee. 1983. The Philippines Recommends for Coconut. Philippine Councfl for Agriculture and Resources Research and Development Technical Bulletin No. 2 A. PCARRD., Los Banos, Laguna Philippines. 89 pp.

The Coconut Committee. 1983 State of the Art: Coconut Research. Philippine Council for Agriculture and Resources Research and Development, Crops Series No.6 PCARRD Los Banos, Laguna, Philippines, 96 pp.

The Committee for Forestry. 1985 The Philippines Recommends for Coconut Timber Utilization. Philippine Council for Agriculture and Resources Research and Development Technical Bulletin Series. No. 60 PCARRD, Laguna, Philippines. 93 pp.

The Committee on Integrated Cattle-Coconut Farming. 1982. The Philippines Recommends for Integrated Cattle-Coconut Farming. Philippine Council for Agriculture and Resources Research and Development. Technical Bulletin Series No.51, Los Banos, Laguna, Philippines. 39 pp. 